ERRATUM

\title{
Case Report 1
}

Nicht-okklusive Mesenterialischämie

bei Sars-CoV 2 Infektion

Mader C, Michalik S, Vogl T. Fortschr Röntgenstr 2021; 193 :

S43. DOI 10.1055/s-0041-1723257

Im oben genannten Artikel wurde der Name zweier Autoren falsch angegeben. Richtig ist: Mader C und Vogl T. 